\title{
A Tale of Odds and Ratios: Political Preference Formation in Postindustrial Democracies
}

\author{
David M. Wineroither $\cdot$ Rudolf Metz
}

Accepted: 12 May 2021 / Published online: 14 July 2021

(C) The Author(s) 2021

\begin{abstract}
This report surveys four approaches that are pivotal to the study of preference formation: (a) the range, validity, and theoretical foundations of explanations of political preferences at the individual and mass levels, (b) the exploration of key objects of preference formation attached to the democratic political process (i.e., voting in competitive elections), (c) the top-down vs. bottom-up character of preference formation as addressed in leader-follower studies, and (d) gene-environment interaction and the explanatory weight of genetic predisposition against the cumulative weight of social experiences.

In recent years, our understanding of sites and processes of (individual) politicalpreference formation has substantially improved. First, this applies to a greater variety of objects that provide fresh insight into the functioning and stability of contemporary democracy. Second, we observe the reaffirmation of pivotal theories and key concepts in adapted form against widespread challenge. This applies to the role played by social stratification, group awareness, and individual-level economic considerations. Most of these findings converge in recognising economics-based explanations. Third, research into gene-environment interplay rapidly increases the
\end{abstract}

David M. Wineroither $(\bowtie) \cdot$ Rudolf Metz

Institute for Political Science, Centre for Social Sciences, Budapest, Hungary

E-Mail: Wineroither.DavidMartin@tk.hu

Rudolf Metz

E-Mail: Metz.Rudolf@tk.hu

David M. Wineroither

Department of Governance and Public Policy, Faculty of Public Governance and International

Studies, University of Public Service, Budapest, Hungary

Rudolf Metz

Department of Political Science, Institute of International, Political and Regional Studies, Corvinus University of Budapest, Budapest, Hungary 
number of testable hypotheses and promises to benefit a wide range of approaches already taken and advanced in the study of political-preference formation.

Keywords Economic voting · Genetic research · Political leadership · Social class $\cdot$ Spatial theory

\section{Wahrscheinlichkeiten und Anteile: Bildung politischer Präferenzen in postindustriellen Demokratien}

Zusammenfassung Dieser Literaturbericht orientiert sich an vier Zugängen bzw. Blickwinkeln, welche die Erforschung der Bildung politischer Präferenzen prägen: (1) die Reichweite, Validität und theoretischen Grundlagen von Erklärungsmodellen auf individueller und Massenebene, (2) die Ergründung von Objekten der Präferenzbildung, die von zentraler Bedeutung für den demokratischen Prozess sind, (3) der Top-down- vs. Bottom-up-Charakter der Präferenzbildung, wie er exemplarisch in der Leader-follower-Literatur der Leadership-Forschung in Erscheinung tritt, sowie (4) das Zusammen- und Wechselspiel von Genetik und Umwelt und der Erklärungsgehalt genetischer Prägung gegenüber den (kumulativen) Einflüssen sozialer Erfahrungen. Diese Forschung hat in der jüngeren Vergangenheit zu einem stark verbesserten Verständnis der Prozesse der Präferenzbildung geführt. Erstens hat sie den Erkenntnisradius erweitert und schließt nun etliche neue Objekte der Präferenzbildung ein, die von wesentlicher Bedeutung für das Funktionieren zeitgenössischer Demokratie sind. Zweitens finden zentrale ältere Theorien und Konzepte in modifizierter Form Bestätigung. Das betrifft etwa die Rolle sozialer Schichtung, von Gruppenbewusstsein und individuellen wirtschaftlichen Abwägungen. Die meisten dieser Befunde verweisen auf eine anhaltende Bedeutung wirtschaftsorientierter Erklärungsansätze. Drittens ermöglicht die - methodisch anspruchs- und voraussetzungsvolle - Erforschung des Wechselspiels zwischen genetisch bedingter Veranlagung und Umweltbedingungen ein Ergründen neuer Testhypothesen und geht mit dem Versprechen einher, bereits etablierte Zugänge zu befruchten bzw. neu zu beleben.

Schlüsselwörter Ökonomisches Wählen · Genetik · Politische Führung · Klassentheorie · Räumliche Modelle

\section{Introduction and Rationale}

In democracies, institutional rules are designed to hold leaders accountable and keep them responsive to the diverse political preferences of the electorate. Preferences rest upon notions of comparative evaluation as part of a larger internal process through which "individuals convert information from their environment into evaluations of political objects" (Druckman and Lupia 2000, p. 8). At the most generalised level and based upon the misleading assumption of full disclosure of their content, these are often referred to as "popular will" in public discourse. 
While care should be taken regarding the pitfalls attached to the perception and interpretation of highly aggregated manifestations of political preferences ("meaningless amalgamations," according to William Riker's verdict; Riker 1982, p. xviii), it is of particular interest to political scientists to ask what accounts for their formation in the first place. In recent years, our understanding of sites and processes of (individual) political-preference formation has substantially improved. For instance, political science has progressed swiftly beyond the simplifying assumptions posed by historical cleavage theory and formal spatial theory, with their common emphasis on competition in the policy domain (Kitschelt 2000). In the field of political economy and political sociology, scholars have adapted social class schemes to the landscapes of professional differentiation prevalent in postindustrial societies (e.g., Oesch 2008). Similarly, common perspectives on leadership roles are being reevaluated: Electoral studies have repeatedly highlighted the important influence that leaders can have on voters' beliefs and behaviour. Furthermore, the call for more follower-centric research has grown steadily louder among scholars of political leadership (Hartley 2018, pp. 209-210).

This review of the literature is concerned with the origins of political preferences and the ways in which they are shaped. It offers a condensed summary of the state of the art and provides a navigation instrument in a vibrant field that is characterised by a combination of multilayered innovations and burdening segmentation. Contemporary research offers a mix of methodological innovation, conceptual clarification, and theory formation that promises to benefit many areas of comparative political research. This research is important also because modes of preference formation, for example, are tightly linked to vital questions of democratic stability, performance, and even survival (e.g., Schedler and Sarsfield 2007; Gherghina and Geissel 2017).

This report surveys four approaches that are pivotal to the study of preference formation: (a) the range, validity, and theoretical foundations of explanations of political preferences at the individual and mass levels, (b) the exploration of key objects of preference formation attached to the democratic political process (i.e., voting in competitive elections), (c) the top-down vs. bottom-up character of preference formation as addressed in leader-follower studies, which has gained prominence due to the trend of personalisation of politics, and (d) gene-environment interaction and the explanatory weight of genetic predisposition against the cumulative weight of social experiences. Each section of the report can be read individually, but the links between these four approaches are made apparent. We provide information on what sets of preferences are addressed by each strand of research, the methods researchers employ, opportunities for interdisciplinary facilitation (e.g., in combination with genetics, labour psychology, and experimental design), and whether recent insights amount to breakthroughs in terms of concept formation and/or the advancement of theoretical propositions.

This survey focuses on stages, sites, and the interpersonal logic of preference formation at the expense of the role of institutions in structuring citizens' need to act strategically (e.g., in connection with solving collective-action problems). We do not seek a novel explanation (or theory thereof) of political-preference formation, but instead introduce the main approaches, core issues, and key findings in this area. The report concludes by identifying common themes at the heart of this research 
and by identifying areas of common ground that may offer a place where research efforts from different specialties may come together to further the understanding of political-preference formation.

\section{Political Conflict and Competition}

Scholarly understanding of political representation has long been guided by two theories of voting: formal spatial theory and cleavage theory. Both are theories of competition in the democratic marketplace that can explain party system dynamics, policy outcomes, and the quality of representation. However, they also address questions of formation, durability, distribution, and composition of preferences. Here the focus is on processes during which voters form preferences as rankings derived from comparative evaluations over limited choice sets.

\subsection{Ideological Proximity and the Pursuit of Self-interest}

Formal spatial theory, inspired by Downs (1957), describes an integrated theory of vote choice, party platform selection, and the quality of outcomes (Hinich and Munger 1997). It is premised on the idea of self-interested choice mediated through ideological proximity. Its key assumption regarding voter preferences is unidimensionality, with each individual voter's preferences single-peaked and the distribution of preferences of all voters approximating a bell-shaped curve (normal, Gaussian distribution). This and other assumptions have come under criticism, and instead a push has been made towards establishing a unified theory of voting, including (a) the number of policy dimensions citing cognitive barriers, (b) the empirical distribution of preferences in the electorate, (c) spatial/directional modelling, and (d) programmatic convergence of parties in order to win over the median voter (for a summary, see Iversen 1994; Adams et al. 2005).

Although spatial modelling has inspired a number of new concepts, most notably veto player theory (Tsebelis 2002), it has more recently been superseded by the concepts of issue salience and issue ownership of parties. These latter concepts have proved to be rather successful in replacing spatial modelling, which has seen refutation in the analysis of the behaviour of many parties, outcomes of elections, and effects of institutional landscapes in nonmajoritarian systems of governing (Stadelmann et al. 2019; Dennison 2019). Issue salience, on the contrary, is associated with contemporary research on the rise of challenger parties, niche parties, and businessfirm parties under entrepreneurial leadership.

Regarding issue ownership of parties, as Bélanger and Meguid (2008) have demonstrated, this phenomenon (Petrocik 1996) guides voters' party preferences only on a selected number of highly salient issues. These often concern valence issues, such as economic voting (see section 3.1). Both mainstream establishment and challenger parties may be forced to engage in "politics of competence" (Green and Jennings 2017), for example when issue ownership passes over from one party to another in times of political or economic shock, and/or because of the costs at- 
tached to governing in terms of shrinking vote share. ${ }^{1}$ It has also been suggested that for many voters, the significance of ownership hinges upon the credibility of issueowning parties' claims to care about implementation (Lachat 2014) —evidence that supports perceptions of voters as working around institutions (e.g., rating chances for supported parties to enter government, improvement by greater ideological proximity compared with the status quo) as featured in the concept of strategic voting.

\subsection{Cleavage Theory and Mass Behaviour}

In contrast to spatial theory, the Rokkanian theory of social cleavages seeks to explain mass political behaviour (Lipset and Rokkan 1967; Bartolini and Mair 1990). Its proponents argue that European party systems are shaped by major historical conflicts over religion, class, and state building that have occurred in modern times. The sequential interaction of these conflicts gave way to stable patterns of sets of preferences and political alliances that became locked into a sociopolitical status quo ("frozen party systems").

Some authors assert that the increasing fluidity of party systems does not invalidate cleavage theory. In this vein, Hooghe and Marks (2018) contend that established parties absorb new cleavages through previously held ideology and commitments. However, given the transformative nature of, in the European context, supranational integration, these parties cannot prevent the rise of challenger parties. Traditional parties face various restrictions ("bounded rationality") that prevent them from taking positions that cut across old and new cleavage structures (Bornschier 2009). They therefore fail to undermine the electoral efforts of challenger parties.

Authors who attribute the continued success of right-wing populist and leftistlibertarian parties to the unleashed forces of globalisation follow a similar trajectory. Merkel and Zürn (2019) argue that opposition to its multifaceted consequences, in particular multiculturalism, resulted in an emerging communitarian-cosmopolitan cleavage also thanks to representational gaps. This new transnational cleavage incorporates some traditional cleavages (e.g., the center-periphery antagonism and the urban-rural divide) while it cuts across others (e.g., the capital-labour conflict) (Merkel and Zürn 2019, p. 97). Norris and Inglehart (2019) go further in explaining the recent series of major populist decisions (e.g., Brexit and the election of Donald Trump) in noneconomic terms as a "cultural backlash." This, however, stands in contrast to findings in the study of opinion formation and vote choice. In fact, political divides along new social risks caused by globalisation and welfare-state retrenchment (e.g., higher exposure to risk of unemployment and lower social benefits associated with atypical employment) and positions regarding immigration and supranationalism do not seem to have greatly diminished the explanatory power of traditional cleavages for mass behaviour, certainly not when it comes to social class (see section 3.3). These new divides share the ability to predict voter preferences at the group level (Enyedi 2008).

In support of both cleavage theory and concepts of issue salience/ownership, there is no indication that a pluralisation of lifestyle and employment situations,

\footnotetext{
1 The recent successes of Blue Toryism in the U.S. and the UK come to mind as an example.
} 
a loosening of tight links between parties and their voters (dealignment; Dalton and Wattenberg 2000), and, to some extent, responsible partisan government gave way to an atomisation of preferences at the individual level or random clustering of preferences across salient political issues. This is indicated, for example, in the realignment of parts of the working class that fuels right-wing populist parties' electoral successes (Arzheimer 2008). At the end of the day, it is still just a handful of party families and party types that take the lion's share of votes in general elections.

What are the types of policies that drive vote choice? For decades and generations, citizens' policy preferences had been mapped onto a single dimension. Voters, politicians, and political scientists had been attracted almost unanimously by the simplicity of this left-right scale (Benoit and Laver 2006). However, while several noteworthy empirical studies continue to generate support for this concept (e.g., Van der Brug and Van Spanje 2009), the emerging consensus has shifted to n-dimensional packaging of underlying preference structures. ${ }^{2}$

The items that constitute each dimension are contested within limits. For postindustrial societies in Western Europe, Kriesi et al. (2006) highlight the impact of European integration as a driving force of preference formation, while Kitschelt and Rehm's (2015) cultural dimension rests upon the collapsing of two separate subdimensions (sociopolitical governance and sociocultural), which points to the salience of migration and identity politics. Häusermann and Kriesi (2015) instead argue that the political space of individual-level voter preferences is characterised rather uniformly throughout European polities by a blurring of the boundaries between economic and cultural conflict. First, they ascribe this effect to the increasing salience of distributive questions regarding welfare chauvinism and welfare misuse, a set of issues tied in large part to supranational integration and immigration. They also regard issues such as redistribution, social investment, and social insurance as not unconditionally aligning on a single dimension.

\subsection{Nonpolicy Modes of Evaluation}

In line with key propositions advanced in spatial modelling, cleavage theory as highlighted in the responsible partisan government tradition confines itself to policies as objects of preference formation. While this specialisation adheres to common ideals of democratic accountability and has enabled a profound understanding of policy-based chains and gaps of representation, it neglects other domains of voter reasoning.

\footnotetext{
2 In a nutshell, postmaterialism and a pluralisation of lifestyle choices have resulted in the emergence of a culturally defined preference dimension that complements rather than replaces the traditional socioeconomically defined (left-right) axis (e.g., Oesch 2012; Rovny 2013). Phenomena such as logrolling, arrow paradox, cyclical majorities, and manipulative framing represent procedural and communicative obstacles to the emergence of coherent preferences on political issues, let alone issue packages and dimensions (Bernholz 1973; Neufeld et al. 1994). However, as Druckman (2004) illustrates, elite competition and interpersonal conversations can overcome these restrictions. Based on experimental design and survey evidence, Lavine et al. (2012) found ambivalent partisanship to facilitate reliance on material interest and core political values. All this evidence points to voters as cognitive misers.
} 
What are the political means and ends that motivate citizens, and which represent their objects of preference formation? Kitschelt and his collaborators on the Democratic Accountability and Linkages Project have strongly argued that representation stretches far beyond policy-based programmatic demand (Kitschelt et al. 2009). In the Western policy-based tradition of cleavage theory and formal spatial theory, other spheres of crafting democratic accountability have received much less attention. This applies to (a) clientelism as part of the world of instrumental calculation and (b) several entities representing the sphere of emotional reasoning, including party identification, charismatic leadership, and ascriptive (formal) representation (Kitschelt 2000).

Citizens form and hold preferences over all these political deliverables. They guide parties' and candidates' choices when deciding to direct their resources with the aim of appealing to voters. In short, while most studies confine themselves to looking at the programmatic structuration of the democratic marketplace, not all voters focus on policy considerations, nor do all voters treat their most important sets of preferences, which are informed by different objects, as separate. Typically, many tend to blend various modes of linkage building. For instance, voters evaluate a political leader's character and competence through the prism of the ideological blueprint of that candidate's party-family membership (Bittner 2011). Another way in which voters bridge instrumental and affective reasoning is in the assignment of issue competence to certain parties, which is mediated through aspects of party identification for most voters, not only party identifiers (Stubager and Slothuus 2013). Finally, it is in the nature of coalition preferences and various forms of strategic voting to incorporate a variety of types of linkages (Plescia and Aichholzer 2017).

The instrumental case of clientelism is somewhat special. A weakness of much of the literature is that it fails to fully appreciate the presence and impact of clientelism on both the supply and demand sides of political competition in mature, affluent democracies. Except for the narrowed-down question of electoral punishment for welfare retrenchment (e.g., Giger and Nelson 2011), the effect of parties' clientelistic engagement in serving individual and group-based preferences remains largely unaddressed (for the U.S., see Ansolabehere and Snyder 2006). The reason for this seems to be a tight perceptual association of clientelism with premodern authoritarian settings and nondemocratic practice. ${ }^{3}$ In the end, the transactional nature of particularistic voting serves rather conventional ends such as jobs, housing, procurement, and social policy. However, it does so at the expense of universalisticegalitarian values (Rawls 1971).

\section{Economic Evaluation and Social Class Revisited}

Citizens form preferences over all sorts of political issues, content, and outcomes. What are common or central objects of preferences to which people pay attention,

\footnotetext{
3 Tellingly, the special issue on "comparing patronage democracies" of Democratization (January 2020) limits itself to highly defective electoral democracies. For the emerging Polish case, see Markowski (2019).
} 
and where does this attention prompt acts of comparative evaluation and ranking? Economic well-being figures prominently among voter reasoning and is treated by voters as both a set of valence issues and a set of positional issues. Research on preferences regarding socioeconomic policies and performances grapples with virtually all major competing theoretical perspectives in the study of preference formation. This includes retrospective voting, the role of an individual's sociotropic considerations, and the dynamic nature of preferences over salient issues.

\subsection{Economic Voting}

As Druckman and Lupia (2000) remind us, selective memory and attentiveness play a crucial role in the regulation of processes of preference formation. Both aspects are highlighted in the study of the role of economic conditions in political-preference formation, which represents a key issue in economic voting theory. According to Zaller and Feldman (1992), economic voting occurs, or is particularly influential, when changes in the economic environment impact people's circumstances, and when these are felt in a relatively rapid fashion (see also Zaller 1992, p. 48). Models of economic voting on valence issues (i.e., unemployment, GDP growth, inflation rate) typically operate within a time frame of 12 to 18 months (e.g., Lewis-Beck 2006; Lewis-Beck and Nadeau 2011). Effects of economic shocks on an individual's policy preferences have recently been found to be of vital importance to actual preferences, but they (a) fade away during economic normalisation and (b) carry little explanatory weight for vote choice (Margalit 2019).

How do voters integrate knowledge of the past, present experiences, and future considerations into their preferential calculus? Fiorina (1981) coined the term "retrospective" voting, which he tied to voters' ability to assess personal as well as macroeconomic circumstances, and to ascribe political responsibility for specific issues encountered personally or by society at large (the "running tally" of party identification). Voters assume that-and test whether-evaluation of past policy performances and promises will hold up in envisaging politics during future electoral and legislative cycles. Lewis-Beck and Stegmaier (2019) recently found that sociotropic (macro-level) retrospective economic evaluations dominate the economic vote choice.

Still, the question remains as to whether preference formation is generally unattached to individual concerns (pocketbook evaluation)? In the end, preferences emerge and/or are shaped by interactions between individuals and their environment (e.g., peers, mentors, groups and masses, birth order within the family). We find ample evidence for the presence of sociotropic evaluations:

- Empirical analyses suggest that individual economic circumstances work in conjunction with individual perceptions of relative positioning in society and sociotropic evaluations of valence issues to shape political preferences (Lewis-Beck 1985; Healy et al. 2017). A number of studies have demonstrated that the relative weight carried by pocketbook vs. sociotropic evaluations in elections is dependent on the specific features of politico-institutional systems, notably driven by divided government and incumbency in presidential systems of government 
(Campbell et al. 2010; for coalition governments in parliamentary systems, see Debus et al. 2014). According to Gomez and Wilson (2001), pocketbook voting is more frequent among more sophisticated voters, who share a better understanding of collective political responsibilities.

- Perceived injustice represents a powerful predictor of political preferences in liberal democracies. Considerations of fairness or "deservingness" are key drivers behind citizens' welfare-state program attitudes (Alesina and Angeletos 2005; Brown-Iannuzzi et al. 2014; Attewell 2021; for the role of civic duty, see Mullinix 2018).

\subsection{New Social Risks}

Of course, an individual's needs in terms of economic and social well-being vary dramatically by age, education, job situation, and family relations. The dynamic, vibrant research on social risks over life cycles takes systematic account of factors such as time variance, individual-level evaluation of long-term prospects, and new societal gaps that have emerged in part from the dissolution of national boundaries (e.g., Wren and Rehm 2013; Schwander 2019). First, what are the types of social risks that shape citizens' preferences over pivotal socioeconomic policies and codetermine party choice? The dominant theoretical approaches to the comparative political economy of the welfare state stipulate that voters evaluate social policy along two dimensions: redistributive effects and risk hedging (Cusack et al. 2006; Rehm 2009; Rehm et al. 2012; Barber et al. 2013). This process is dynamic and incorporates retrospective and prospective evaluation. As Iversen and Soskice (2001) highlight in their asset theory of social policy preference formation, citizens try to strike a balance between past investment, current consumerism, and future-directed risk hedging.

In terms of party choice, it is important to note that governments frequently choose to intervene in this process by mediating work-related risk exposure (and individual risk perception): clientelistic action that comes with significant redistributive consequences (see the section on clientelism below). This applies to job security and uncertainty about future income, but also to access to social entitlements and risk buffering. The literature on "dualisation" that has gained prominence-alongside risk-based individual-level approaches - sees the interests of "insiders" and "outsiders" (e.g., immigrants, the atypically employed) as pitted against each other (Rueda 2007; Rueda and Stegmueller 2019; Dimick et al. 2018). This points to the permeability of national labour markets. As Rommel and Walter (2018) demonstrate, offshoreability and selective political clientelism (shelterism) have started to impact the political-party choice preferences of voters.

\subsection{Social Class}

Economic models of electoral forecasting portray preference formation as temporal, dynamic, and comparatively independent of group awareness. This assessment has generally been in line with a myriad of contributions from various fields and disciplines that found a vanishing impact of vertical stratification, i.e., impact of social 
class on preference formation in pluralist, open societies with postindustrial labour markets (Clark and Lipset 2001; Evans 2000; Evans and Tilley 2012). More recently, authors have attempted to reconcile the traditional class concept with a shifting class structure, arguing that neither the simplicity of the Alford index (a simple distinction between blue-collar and white-collar voters) nor the post-Weberian class scheme of Erikson/Goldthorpe/Portocarero (EGP), which already highlighted the importance of occupational background and market prospects rather than pure asset ownership, are able to take fully into account the presence of new task structures and work logics, social risks, and risk-hedging strategies in service economies.

Oesch's class scheme, on the contrary, focusses on the level of marketable skills and operational work logic to distinguish social strata $(2006,2008)$. His work highlights differentiation within the middle class (i.e., low-skilled service workers who face sustained constraint on wage growth). The new framework depicts a rotating primary axis of preferential polarisation that helps to explain the defection of (a) production workers towards the radical/populist right and (b) highly educated sociocultural professionals in possession of high levels of marketable skills favouring leftist-libertarian movements across polities (Oesch 2012). Similarly, Kitschelt and Rehm (2014) incorporate organisational theory and labour psychology to establish class boundaries. The authors claim that generalisation and transposition permitted by work experiences exert a major influence on the formation of political attitudes in general (for Germany, based upon a similar framework, see Müller and Klein 2012). ${ }^{4}$

This reenergising of the class concept in political science also represents a pushback against claims of social destratification, decomposition of group thinking, and the predominance of identity politics and cultural issues in general. Based on the adapted framework advanced in the work of Oesch, Kitschelt and Rehm and others, social class background indeed has been shown to inform an individual's preferences across key policies/issues in a theoretically consistent and predictable way (Oesch 2012; Lefkofridi et al. 2014; Kitschelt and Rehm 2014; Beramendi et al. 2015; Thewissen and Rueda 2019). It relates to insights from the literature on social-policy preference formation that attributes the formation of social risks and shaping of social-policy preferences to individual occupational characteristics rather than to industry-level propensities (Rehm 2009).

These conceptual adaptations to postindustrial stratification have come under little scrutiny thus far. Regrettably, net effects on, for example, vote choice and sets of key programmatic issues are rarely tested in a comprehensive manner. However, neoinstitutionalists remain suspicious regarding the homogeneity of collapsed classes (e.g., the eight-class scheme introduced by Oesch in 2006) and insist on stratification within certain classes (for sociocultural professionals, see Hall 2016, p. 386).

\footnotetext{
${ }^{4}$ Most studies in this field rely on the International Labor Organization's elaborate ISCO-coding scheme featured in the European Social Survey. KLEMS data released by the European Union adds valuable items at the household level.
} 


\section{Top-down or Bottom-up? Leaders and Followers}

Similar to clientelistic particularism, citizen preferences that are attached to political leaders are in need of reconciliation with democratic core values. Leadership is at odds with democratic routine politics, at least if defined as making a difference to the lives of many people through leadership qualities and styles that are rooted in character traits (e.g., erratic behaviour rooted in low self-esteem that causes diplomatic failure of large-scale consequence, including the outbreak of war, a government shutdown, or provoking of a systemic crisis). ${ }^{5}$ Revealingly, personalism and charismatic leadership feature prominently in concepts that deal with democratic imperfections, including populism, anti-institutionalism, and authoritarian political views (Adorno et al. 1982; Malka et al. 2020). ${ }^{6}$

Despite notions of a hollowing out of leadership, notably in compound (semisovereign) polities and countries characterised by excessive party government (e.g., Belgium and Italy), leaders and leader-follower relations represent both a relevant subject and an object in the study of preference formation. On the one hand, political science has shown a growing interest in studying the effects of personalistic relationships between leaders and followers. On the other hand, the advent of follower-centric approaches of generic leadership studies provides an indepth look into the nature of political followership.

\subsection{Charismatic Leadership and Democratic Personalism}

Political science has long considered the influence of political leaders on citizens' political behaviour to be limited in comparison with other influences, such as parties or ideologies. This view has been partly eroded over the past 20 years. Many researchers recognise that modern democratic politics has become more personalised (Poguntke and Webb 2005; Rahat and Kenig 2018; Pedersen and Rahat 2019) and that it generates more significant leader effects than it did in the past, at least at the polls. That said, net effects in the arena of electoral politics and linkage building are hard to establish. Direct effects should not be overestimated, as citizens/voters tend to perceive both parties and candidates through the lens of partisanship and ideological proximity. In other words, the evaluation of leaders appears mediated through preferences preformed elsewhere (see section 2.3).

Nevertheless, individual political actors are directly and indirectly more important, and they are clearly more visible in the process of preference formation relative to structural factors than suggested by, for example, cleavage theory and advocates of social stratification causality. Where does the influence of individual political actors come from? Personalised politics is twofold. First, politicians seek to capture the centre stage of politics and convey a favourable personal image. Second, citizens'

\footnotetext{
${ }^{5}$ Even in times of acute crisis rooted in existential threats, public preference has exerted pivotal restraining influence upon executive power. See Abendroth's (1964: 309) praise for Churchill's failed reelection bid in 1945.

${ }^{6}$ Correspondingly, we observe a reduced academic interest in the mentality and attitudes of collectives such as legislators (Kam 2001; Ringe 2005) and political elites in general.
} 
and politicians' individual personalities, traits, and values are crucial in the process of translating preferences into actual decisions. For example, the valence model of personalised politics (Clarke et al. 2004) suggests that voters seek to support those leaders who appear more competent (effective) in comparison with other contenders. In a similar vein, Caprara and Zimbardo's (2004) empirical model of leader-voter congruency emphasises the importance of trait-based similarities. According to their model, voters seek and support politicians who match their own personality. They note the following:

We want to trust competent leaders, but we also want to like them personally, and this is easier when they are perceived as essentially similar to us. The extent to which voters perceive their leaders' personalities as similar to their own is critical in humanizing abstract icons and endorsing politicians' efforts and claims (Caprara and Zimbardo 2004, p. 590).

The findings on personalisation and the impact of leaders on voting behaviour are mixed and inevitably inconsistent because studies have not followed a clear and unified conceptual and methodological approach to understanding the dynamics of political leadership in the electoral context. These studies face three limitations. First, studies of personalised politics struggle with severe conceptual uncertainty (Pedersen and Rahat 2019; Pruysers et al. 2018). Second, the different factors (ideology, cases, parties, and leaders) and their effects upon citizen preferences have always been difficult to separate, resulting in a logical loop between independent and dependent variables (the problem of endogeneity; Garzia 2014). Third, the personaltrait approach that researchers apply when they focus on perceptions of leaders' and followers' values, traits, and personalities (Caprara and Zimbardo 2004) is insufficient to understand the complex dynamics involving the effects of leadership on preference formation.

In addition to the study of leaders' effects on electoral outcomes, the research has also given attention to the "follow-the-leader" behaviour from leaders' effects on electoral outcomes, shedding light on the complex relationship between leaders and followers' preferences. Challenging conventional wisdom about leader effects, scholars have found that leader cues - the political actors' position-taking on a policy issue - significantly impact public opinion, resulting in changes in voter preferences. Gabriel Lenz (2012) demonstrated in Follow the Leader? that people first choose what political leader they want to support and then adopt their policy view, rather than the other way around. In short, people modify their opinions to match their leaders' preferences. A series of studies also very recently provided strong empirical evidence for this argument: Citizens still support their preferred leaders even when the leaders in question find themselves taking public policy positions which were previously supported by rival parties or which they had opposed when they were not in government (Agadjanian 2020; Barber and Pope 2019; Broockman and Butler 2017). In turn, this makes citizens vulnerable, as leaders may not act like voter agents, and consequently, it can be questioned whether such leaders recognise voters as principals; leaders do not act like their "agents" or recognise them as "principals." Based on an impressive data-gathering operation, Druckman and Jacobs (2015) in 
Who Governs ?7 $^{7}$ unveil possibilities for U.S. presidents to pursue effective agenda manipulation (compare the concept of heresthetics in Riker 1986).

\subsection{Bottom-up Follower Centrism}

One question remains open: Why do people choose a particular leader to follow? Public and political leadership studies have not yet provided an answer to this question. Although the research community has recently been calling for more followercentric research, (Blondel 2014, pp. 711-712; Hartley 2018, pp. 209-210), political leadership studies tend to remain overly leader-centric, focusing mainly on incumbent politicians' resources, formal positions, and institutional context (e.g., Bennister et al. 2017; Elgie 2018). From this perspective, the support of citizens is viewed only as a resource or an outcome of leadership.

In contrast, for follower-centric models of leadership (Shamir 2009), the question is not how citizens change their preferences and cast their votes due to the (re)evaluation of leaders' political characters, but how they follow and can even control leaders' behaviour. As followers perceive and evaluate politicians' actions and effectiveness, they project their expectations onto leadership-process-making leaders to meet those. However, some leaders also can manipulate and create an idealized image of themselves. This relationship goes beyond descriptive representation or principal-agent relations. Followers become attached to leaders and follow them, not because of their characteristics or behaviour, but because the leader symbolises a prototypical, idealistic figure who is able to reduce anxiety, provide psychological safety, authentically represent the values and interest of the voter's group, and overcome collective challenges.

With their interdisciplinary approach (e.g., social psychology) and mixed methodology (e.g., controlled experiments and public and expert surveys; Marino et al. 2018), general leadership studies deal only partly with political actors (e.g., Carsten et al. 2019), but their conceptual background and valuable findings can lead us to a deeper understanding of the effects of leadership concerning issues such as trust, perceived effectiveness, and charisma. For example, it has been found that voters are more likely to evaluate a leader from their own political party as charismatic (Alabastro et al. 2013; Pillai et al. 2003; Pillai and Williams 1998; Shamir 1994; Williams et al. 2018; see section 2.3). ${ }^{8}$ For leaders, representing key attributes of their groups (e.g., attitudes, values, and behaviours) is crucial for generating followership. Perceived group representation (i.e., "group prototypicality") results in stronger identification with leaders, closer personal bonds, and greater charisma (Steffens et al. 2014). Moreover, if leaders embody ideal-type group members, they can gain more trust and are seen as more effective, even after a negative outcome (Giessner et al. 2009). For instance, Donald Trump's electoral success in 2016 could be explained by his ability to more effectively represent his group of voters. Accord-

\footnotetext{
7 The authors picked this title to honour the groundbreaking work of Robert Dahl.

8 Psychological scholarship on the influence of facial cues (e.g., Alrajih and Ward 2014) and voice upon charismatisation has been scarcely received in the field of political leadership studies, which is clearly focussed on rhetorical skills as a politician's means to fully exploit charismatic appeal.
} 
ing to the perceptions of Republican voters interviewed by Christian et al. (2018), they perceived Trump as embodying his party's values more than Democrat voters perceived Hillary Clinton as representing the values of her party.

\section{5 (Non)Staggered Genetics}

Preference formation in the political realm is influenced by birth circumstances, early childhood environment, family relations, exposure-or lack thereof—to various life hazards, and occupational characteristics, as well as cumulative social experiences. Indeed, political preferences never cease to evolve.

\subsection{Genetic Predisposition and Determinism}

Genetic predisposition also appears to play a role in this process. The behaviour-genetic approach has been used to analyse a great variety of political phenomena, encompassing topics such as political extremism (Ksiazkiewicz and Krueger 2017) and foreign policy preferences (Stam et al. 2012). Voters' degree of political knowledge, a key variable widely used in comparative political research, has been investigated within the framework of twin studies (Hannagan et al. 2014; see also Littvay 2019). Most of these studies found evidence for genetic roots in variations in individual behaviour and preferences. As individuals grow older, genetic effects seem to be preserved and remain influential against the cumulative weight of social experiences. Unsurprisingly, studies that trace the basic ideological orientation of eligible voters back to genetic predispositions are prone to receiving their fair share of media attention, including coverage by The New York Times (e.g., Hatemi et al. 2014). The interactive effects between genes and environment have not yet been established, though.

Some authors have gone so far as to argue that genes exert a crucial influence upon political attitudes, values, and preferences. Fowler and Dawes (2008), for example, causally linked voter turnout to a simple association between two genes. Similarly, as part of a meta-study on the influence of genetics on preference formation, Hatemi et al. (2014) nominated isolated genes as exerting insular influence upon items such as political interest and core beliefs (see similar, Weinschenk et al. 2021). Politicobiologists have delved into the physiological roots of the link between genes and individual human predisposition towards politics by manipulation of brain activity. In a study by Benjamin et al. (2012), the authors used dense singlenucleotide polymorphisms to trace molecular genetics-based heritability, which can be explained by a great variety of genes.

\subsection{Gene-environment Interplay}

Genetic-predisposition research has raised the serious prospect of researchers being able to manipulate individuals' preferences, or at least attitudes and value-orientations, through biochemical means. This raises questions both about free (political) will and of fabricating preferences. Implicit claims of biochemical determinism have 
been met with criticism and have reinvigorated resistance to nature-based physiological studies among social scientists (Bartels 2013). That said, the genetics and heritability of political values represent just one of several emerging areas of biopolitics research. The dominant paradigm has gradually shifted away from orthodox notions of causality and determinism of variation in human microbiomes towards chronobiology (e.g., effects of sleep deprivation on political decision-making), and gene-environment interplay (Ksiazkiewicz and Jung 2020). The latter is of prime relevance for the study of preference formation.

Both social scientists and scholars of physiological processes (e.g., neuroscience, evolutionary psychology, and psychophysiology) have increasingly focussed on overcoming the nature-nurture dichotomy. It has been generally recognised that "[T]heories of human cognition are ultimately theories of physical, biological systems" (Newell 1990, p. 42). However, solely deterministic views have been rejected, with the argument being made that complex traits involve proteins encoded into large sets of genomes, and the interactive effects change over time. Furthermore, as Charney and English (2012, p. 30; see also Littvay 2020) emphasise,

[O]ne of the major theoretical conclusions to emerge from the discipline of computational and systems biology, which attempts to mathematically model biological networks, is that causation in bio-logical systems runs in both directions: upward from the molecular level (which includes the genome and the epigenome) and downward from all other levels: cellular tissue, organ, organism, and external environment.

This emphasis on permanent feedback and feedforward loops already resembles the outline of Druckman and Lupia (2000), who stress patterns of adaption and ranking procedures in preference formation: "[A] preference serves as a cognitive marker that reminds people how to interact with various aspects of their environment" (2000, p. 2) Therefore, the approaches taken by social scientists and scholars of physiological processes in the study of preference formation seem to be generally compatible.

\section{Summary and Outlook}

What are the major lessons to draw from this survey into contemporary scholarship on political-preference formation? Despite advances made in many areas, there is no indication of an emerging consensus on key questions such as the changeability of preferences. This is a direct consequence of the multiplicity of approaches and methods that have been used and the myriad of social phenomena addressed. This, in turn, has led to progress in two areas. First, our understanding of processes of preference formation has advanced significantly and now engages with a greater variety of objects (e.g., the entanglement of policy and nonpolicy domains of evaluations). Second, we observe the reaffirmation of pivotal theories and key concepts in adapted form against widespread challenge. This applies to the roles played by 
social stratification, group awareness, and individual-level economic considerations. Most of these findings converge in recognising economics-based explanations. ${ }^{9}$

Other strands provide great insight into the functioning and stability of contemporary democracy. Despite conceptual and methodological problems, political science was able to point out the impact of personalistic relationships on key political phenomena such as policy choice and voting behaviour. Whether it is viewed from a leader's or followers' perspective, the leader-follower relationship is one of the central dynamics of preference formation. This paradigmatic shift closely reflects upon the embeddedness of governance and political competition in the web of cultural diversity, personalisation, digitalisation, and political mobilisation that characterises today's Western societies.

In this spirit, we consider political polarisation to be a particularly fruitful area for future research. It has been established that the polarisation of preferences at the mass level endangers democratic stability and performance (Graham and Svolik 2020). Besides economic conditions that are more diverse than during the era of welfare-state expansion following World War II, what else is contributing to increasing polarisation? As much as we should refrain from assuming that trends of personalisation of politics lead to increased changeability of preferences and democratically deficient practice, the rise of social media, routinely perceived as the "dark side" of social engagement (Vassallo 2020), should not be automatically equated with (increased) social and political polarisation. First, the influence of social media upon political-preference formation appears to be not only ambiguous but also overrated compared with the influence exerted by political elite behaviour, political misinformation campaigns, and the use of conventional media (Tucker et al. 2018). Second, the echo-chamber effects generated by social media usage can be countered by peer mediation and individuals having diverse social ties (Messing and Westwood 2014; Anspach 2017). While network heterogeneity and cross-cutting exposure, in turn, do not automatically lead to depolarisation (Lee et al. 2014), it seems important to explore (a) the origins of citizens' motivation to seek reinforcement of their political views, (b) the mechanisms they utilise for this purpose (e.g., self-selection), and (c) the effects of different modes of preference formation on the degree of polarisation.

Looking at methodology, experimental design promises to increase the number of testable hypotheses (Druckman et al. 2011; Druckman and Lupia 2012). Controlled settings of exploration enable efforts to unravel confounding variables, which in turn promote our understanding of the explanatory weight attached to hitherto either unsystematically related or competing approaches. For example, epigenetics, which is the study of processes in which heritable phenotype changes take place in the absence of alterations in the DNA sequence, represents a potential key to discover and describe clearer mechanisms explaining the effects of genetic interindividual

\footnotetext{
9 The continued influence of social-class membership implies that key preferences among individuals are relatively stable. The resilience of the concept of party identification and the weight of socioeconomic evaluations point in the same direction. That said, plenty of studies indicate a growing potential for volatility of preferences rooted in, for example, late campaign dynamics fostered by the personalisation of democratic processes (Ekstrom and Federico 2019) and event-based reconsideration (Landau-Wells and Saxe 2020).
} 
differences on the evolution of preference formation. Epigenetic studies allow the analysis of temporal variability in gene expression within individuals, both in the short term (e.g., over the course of an election cycle) and in the long term (e.g., looking at life-course effects).

In other words, this perspective potentially addresses the divisions that set apart major strands of research, demarcation lines drawn over issues such as the heritability of political preferences and attitudes, the role played by sociotropy, and retrospectiveness (i.e., experiences with and knowledge of political actors' past performance) in forming preferences based on considerations of economic well-being.

Clearly, studying preference formation calls for an interdisciplinary approach. Genetic predisposition, the pursuit of economic self-interest, and the web of social interactions that ties individuals to groups and society (Laitin and Wildavsky 1988) play a distinct but unequal role in the formation of political preferences. The challenge for future research is no less than to close theoretical and empirical gaps in the study of "how [...] environments, including social and political institutions, shape our biology and how [...] our biology affects our environments" (Ksiazkiewicz and Jung 2020, p. 14).

Altogether, research into gene-environment interplay comes with profound checks on the robustness of empirical findings by gaining the ability "to test complex genetic and social pathways from attitudes to decisions" (Littvay 2020, p. 14). The lessons scientists will be able to take from such research promise to benefit a wide range of approaches already taken and advanced in the study of politicalpreference formation!

Acknowledgements We wish to thank Kirsty Stone-Weiler, Márton Bene, Levente Littvay, Eric Linhart, and all involved editors for their valuable comments and suggestions.

Funding This work was supported by the Hungarian Scientific Research Fund (PD 134685) and the Center for Social Sciences' Incubator Fund (SHELTER).

Funding Open access funding provided by Centre for Social Sciences.

Open Access This article is licensed under a Creative Commons Attribution 4.0 International License, which permits use, sharing, adaptation, distribution and reproduction in any medium or format, as long as you give appropriate credit to the original author(s) and the source, provide a link to the Creative Commons licence, and indicate if changes were made. The images or other third party material in this article are included in the article's Creative Commons licence, unless indicated otherwise in a credit line to the material. If material is not included in the article's Creative Commons licence and your intended use is not permitted by statutory regulation or exceeds the permitted use, you will need to obtain permission directly from the copyright holder. To view a copy of this licence, visit http://creativecommons.org/licenses/by/4.0/.

\section{References}

Abendroth, Wolfgang. 1964. Innerparteiliche und Innerverbandliche Demokratie als Voraussetzung der Politischen Demokratie. Politische Vierteljahresschrift 5(3):307-338.

Adams, James, Samuel Merrill, and Bernard Grofman. 2005. A unified theory of party competition: a crossnational analysis integrating spatial and behavioral factors. Cambridge, New York: Cambridge University Press.

Adorno, T.W., Else Frenkel-Brunswik, Daniel Levinson, and R. Nevitt Sanford. 1982. The authoritarian personality. In Studies in prejudice, ed. Max Horkheimer, Samuel H. Flowerman, 12. New York: W.W. Norton.

Agadjanian, Alexander. 2020. When do partisans stop following the leader? Political Communication https://doi.org/10.1080/10584609.2020.1772418. 
Alabastro, Alexis, David E. Rast, Andrew Lac, Michael A. Hogg, and William D. Crano. 2013. Intergroup bias and perceived similarity: effects of successes and failures on support for in- and outgroup political leaders. Group Processes \& Intergroup Relations 16(1):58-67.

Alesina, Alberto, and George-Marios Angeletos. 2005. Fairness and redistribution. American Economic Review 95(4):960-980. https://doi.org/10.1257/0002828054825655.

Alrajih, Shuaa, and Jamie Ward. 2014. Increased facial width-to-height ratio and perceived dominance in the faces of the UK's leading business leaders. British Journal of Psychology 105(2):153-161. https:// doi.org/10.1111/bjop.12035.

Ansolabehere, Stephen, and James M. Snyder. 2006. Party control of state government and the distribution of public expenditures. The Scandinavian Journal of Economics 108(4):547-569.

Anspach, Nicolas M. 2017. The new personal influence: how our Facebook friends influence the news we read. Political Communication 34(4):590-606.

Arzheimer, Kai. 2008. Protest, neo-liberalism or anti-immigrant sentiment: what motivates the voters of the extreme right in Western Europe? Zeitschrift für Vergleichende Politikwissenschaft 2(2):173. https:// doi.org/10.1007/s12286-008-0011-4.

Attewell, David. 2021. Deservingness perceptions, welfare state support and vote choice in Western Europe. West European Politics 44(3):611-634. https://doi.org/10.1080/01402382.2020.1715704.

Barber, Michael, and Jeremy C. Pope. 2019. Does party trump ideology? Disentangling party and ideology in America. American Political Science Review 113(1):38-54.

Barber, Benjamin, Pablo Beramendi, and Erik Wibbels. 2013. The behavioral foundations of social politics: evidence from surveys and a laboratory democracy. Comparative Political Studies 46(10):1155-1189. https://doi.org/10.1177/0010414012472467.

Bartels, Larry. 2013. Your genes influence your political views. So what? https://www.washingtonpost. com/news/monkey-cage/wp/2013/11/12/your-genes-influence-your-political-views-so-what/. Accessed 8 Feb 2021.

Bartolini, Stefano, and Peter Mair. 1990. Identity, competition and electoral availability: the stabilisation of European electorates 1885-1985. Cambridge: Cambridge University Press.

Bélanger, Éric, and Bonnie M. Meguid. 2008. Issue salience, issue ownership, and issue-based vote choice. Electoral Studies 27(3):477-491. https://doi.org/10.1016/j.electstud.2008.01.001.

Benjamin, D.J., D. Cesarini, M.J.H.M. van der Loos, C.T. Dawes, P.D. Koellinger, P.K.E. Magnusson, C.F. Chabris, D. Conley, D. Laibson, M. Johannesson, and P.M. Visscher. 2012. The genetic architecture of economic and political preferences. Proceedings of the National Academy of Sciences 109(21):8026-8031. https://doi.org/10.1073/pnas.1120666109.

Bennister, Mark, Paul 't Hart, and Ben Worthy. 2017. The leadership capital index: a new perspective on political leadership. Oxford: Oxford University Press.

Benoit, Kenneth, and Michael Laver. 2006. Party policy in modern democracies. London: Routledge. Transferred to digital print.

Beramendi, Pablo, Silja Häusermann, Herbert Kitschelt, and Hanspeter Kriesi (eds.). 2015. The politics of advanced capitalism. Cambridge: Cambridge University Press.

Bernholz, Peter. 1973. Logrolling, arrow paradox and cyclical majorities. Public Choice 15(1):87-95. https://doi.org/10.1007/BF01718844.

Bittner, Amanda. 2011. Platform or personality? The role of party leaders in elections. Oxford: Oxford University Press.

Blondel, Jean. 2014. What have we learned? In The Oxford handbook of political leadership Oxford handbooks in politics \& international relations., ed. R.A.W. Rhodes, Paul 't Hart. Oxford: Oxford University Press.

Bornschier, Simon. 2009. Cleavage politics in old and new democracies. Living Reviews in Democracy https://doi.org/10.5167/uzh-26412.

Broockman, David E., and Daniel M. Butler. 2017. The causal effects of elite position-taking on voter attitudes: field experiments with elite communication. American Journal of Political Science 61(1):208-221.

Brown-Iannuzzi, Jazmin, Kristjen Lundberg, Aaron Kay, and Brian Payne. 2014. Subjective status shapes political preferences. Psychological science https://doi.org/10.1177/0956797614553947.

Campbell, James E., Bryan J. Dettrey, and Hongxing Yin. 2010. The theory of conditional retrospective voting: does the presidential record matter less in open-seat elections? The Journal of Politics 72(4):1083-1095. https://doi.org/10.1017/S002238161000054X.

Caprara, Gian Vittorio, and Philip G. Zimbardo. 2004. Personalizing politics: a congruency model of political preference. American Psychologist 59(7):581-594. 
Carsten, Melissa K., Michelle C. Bligh, Jeffrey C. Kohles, and Vienne Wing-Yan Lau. 2019. A followercentric approach to the 2016 US presidential election: candidate rhetoric and follower attributions of charisma and effectiveness. Leadership 15(2):179-204.

Charney, Evan, and William English. 2012. Candidate genes and political behavior. American Political Science Review 106(1):1-34. https://doi.org/10.1017/S0003055411000554.

Christian, Julie, Daniella Nayyar, Ronald Riggio, and Dominic Abrams. 2018. Them and us: Did Democrat inclusiveness and Republican solidarity lead to the 2016 US presidential election outcome? Leadership 14(5):524-542.

Clark, Terry Nichols, and Seymour Martin Lipset (eds.). 2001. The breakdown of class politics: a debate on post-industrial stratification. Washington, D.C; Baltimore: Woodrow Wilson Center Press; Johns Hopkins University Press.

Clarke, Harold D., David Sanders, and Marianne C. Stewart. 2004. Political choice in Britain. Oxford; New York: Oxford University Press.

Cusack, Thomas, Torben Iversen, and Philipp Rehm. 2006. Risks at work: the demand and supply sides of government redistribution. Oxford Review of Economic Policy 22(3):365-389.

Dalton, Russell J., and Martin P. Wattenberg. 2000. Parties without partisans: political change in advanced industrial democracies. Oxford; New York: Oxford University Press.

Debus, Marc, Mary Stegmaier, and Jale Tosun. 2014. Economic voting under coalition governments: evidence from Germany. Political Science Research and Methods 2(1):49-67. https://doi.org/10.1017/ psrm.2013.16.

Dennison, James. 2019. A review of public issue salience: concepts, determinants and effects on voting. Political Studies Review 17(4):436-446.

Dimick, Matthew, David Rueda, and Daniel Stegmueller. 2018. Models of other-regarding preferences, inequality, and redistribution. Annual Review of Political Science 21(1):441-460. https://doi.org/10. 1146/annurev-polisci-091515-030034.

Downs, Anthony. 1957. An economic theory of democracy. New York: Harper \& Row.

Druckman, James N. 2004. Political preference formation: competition, deliberation, and the (ir)relevance of framing effects. American Political Science Review 98(4):671-686. https://doi.org/10.1017/ S0003055404041413.

Druckman, James N., and R. Jacobs Lawrence. 2015. Who governs? Chicago: University of Chicago Press.

Druckman, James N., and Arthur Lupia. 2000. Preference formation. Annual Review of Political Science 3(1):1-24. https://doi.org/10.1146/annurev.polisci.3.1.1.

Druckman, James N., and Arthur Lupia. 2012. Experimenting with politics. Science 335(6073):1177-1179. https://doi.org/10.1126/science.1207808.

Druckman, James N., Donald P. Green, James H. Kuklinski, and Arthur Lupia. 2011. Experimentation in political science. In Cambridge handbook of experimental political science, ed. James N. Druckman, Donald P. Green, James H. Kuklinski, and Arthur Lupia, 3-12. Cambridge: Cambridge University Press.

Ekstrom, Pierce D., and Christopher M. Federico. 2019. Personality and political preferences over time: evidence from a multiwave longitudinal study. Journal of Personality 87(2):398-412. https://doi.org/ 10.1111/jopy.12398.

Elgie, Robert. 2018. Political leadership: a pragmatic institutionalist approach. London: Palgrave Macmillan.

Enyedi, Zsolt. 2008. The social and attitudinal basis of political parties: cleavage politics revisited. European Review 16(3):287-304. https://doi.org/10.1017/S1062798708000264.

Evans, Geoffrey. 2000. The continued significance of class voting. Annual Review of Political Science 3:401-417. https://doi.org/10.1146/annurev.polisci.3.1.401.

Evans, Geoffrey, and James Tilley. 2012. The depoliticization of inequality and redistribution: explaining the decline of class voting. The Journal of Politics 74(4):963-976. https://doi.org/10.1017/ s0022381612000618.

Fiorina, Morris P. 1981. Retrospective voting in American national elections. New Haven-London: Yale University Press.

Fowler, James H., and Christopher T. Dawes. 2008. Two genes predict voter turnout. The Journal of Politics 70(3):579-594. https://doi.org/10.1017/S0022381608080638.

Garzia, Diego. 2014. Personalization of politics and electoral change. London: Palgrave Macmillan.

Gherghina, Sergiu, and Brigitte Geissel. 2017. Linking democratic preferences and political participation: evidence from Germany. Political Studies 65(1):24-42. https://doi.org/10.1177/0032321716672224. 
Giessner, Steffen R., Daan van Knippenberg, and Ed Sleebos. 2009. License to fail? How leader group prototypicality moderates the effects of leader performance on perceptions of leadership effectiveness. The Leadership Quarterly 20(3):434-451.

Giger, Nathalie, and Moira Nelson. 2011. The electoral consequences of welfare state retrenchment: blame avoidance or credit claiming in the era of permanent austerity? European Journal of Political Research 50(1):1-23. https://doi.org/10.1111/j.1475-6765.2010.01922.x.

Gomez, Brad T., and J. Matthew Wilson. 2001. Political sophistication and economic voting in the American electorate: a theory of heterogeneous attribution. American Journal of Political Science 45(4):899-914. https://doi.org/10.2307/2669331.

Graham, Matthew H., and Milan W. Svolik. 2020. Democracy in America? Partisanship, polarization, and the robustness of support for democracy in the United States. American Political Science Review 114(2):392-409. https://doi.org/10.1017/S0003055420000052.

Green, Jane, and Will Jennings. 2017. The politics of competence: parties, public opinion and voters. http:// ebooks.cambridge.org/ref/id/CBO9781316662557. Accessed 8 Feb 2021.

Hall, Peter A. 2016. Contribution to a symposium on the politics of advanced capitalism, Pablo Beramendi et al. eds. Socio-Economic Review 14(2):383-394.

Hannagan, Rebecca J., Levente Littvay, and Sebastian Adrian Popa. 2014. Theorizing sex differences in political knowledge: insights from a twin study. Politics \& Gender 10(01):89-114. https://doi.org/10. 1017/S1743923X1300055X.

Hartley, Jean. 2018. Ten propositions about public leadership. International Journal of Public Leadership 14(4):202-217.

Hatemi, Peter K., Sarah E. Medland, Robert Klemmensen, Sven Oskarsson, Levente Littvay, Christopher T. Dawes, Brad Verhulst, Rose McDermott, Asbjørn Sonne Nørgaard, Casey A. Klofstad, Kaare Christensen, Magnus Johannesson, Patrik K.E. Magnusson, Lindon Eaves, and Nicholas G. Martin. 2014. Genetic influences on political ideologies: twin analyses of 19 measures of political ideologies from five democracies and genome-wide findings from three populations. Behavior Genetics 44(3):282-294. https://doi.org/10.1007/s10519-014-9648-8.

Häusermann, Silja, and Hanspeter Kriesi. 2015. What do voters want? Dimensions and configurations in individual-level preferences and party choice. In The politics of advanced capitalism, ed. Pablo Beramendi, Silja Häusermann, Herbert Kitschelt, and Hanspeter Kriesi, 202-230. New York: Cambridge University Press.

Healy, Andrew J., Mikael Persson, and Erik Snowberg. 2017. Digging into the pocketbook: evidence on economic voting from income registry data matched to a voter survey. American Political Science Review 111(4):771-785. https://doi.org/10.1017/S0003055417000314.

Hinich, Melvin J., and Michael C. Munger. 1997. Analytical politics. https://www.cambridge.org/core/ books/analytical-politics/867D13CB9D48D965F88F65E72417ABF7. Accessed 8 Feb 2021.

Hooghe, Liesbet, and Gary Marks. 2018. Cleavage theory meets Europe's crises: Lipset, Rokkan, and the transnational cleavage. Journal of European Public Policy 25(1):109-135. https://doi.org/10.1080/ 13501763.2017.1310279.

Iversen, Torben. 1994. The logics of electoral politics: spatial, directional, and mobilizational effects. Comparative Political Studies 27(2):155-189. https://doi.org/10.1177/0010414094027002001.

Iversen, Torben, and David Soskice. 2001. An asset theory of social policy preferences. American Political Science Review 95(4):875-893. https://doi.org/10.1017/S0003055400400079.

Kam, Christopher. 2001. Do ideological preferences explain parliamentary behaviour? evidence from Great Britain and Canada. The Journal of Legislative Studies 7(4):89-126. https://doi.org/10.1080/ 714003894.

Kitschelt, Herbert. 2000. Linkages between citizens and politicians in democratic polities. Comparative Political Studies 33(6/7):845-879. https://doi.org/10.1177/001041400003300607.

Kitschelt, Herbert, Kent Freeze, Kiril Kolev, and Yi-Ting Wang. 2009. Measuring democratic accountability: an initial report on an emerging data set. Revista de ciencia política (Santiago) 29(3):741-773. https://doi.org/10.4067/S0718-090X2009000300004.

Kitschelt, Herbert, and Philipp Rehm. 2014. Occupations as a site of political preference formation. Comparative Political Studies 47(12):1670-1706. https://doi.org/10.1177/0010414013516066.

Kitschelt, Herbert, and Philipp Rehm. 2015. Party alignments: change and continuity. In The politics of advanced capitalism, ed. Pablo Beramendi, Silja Häusermann, Herbert Kitschelt, and Hanspeter Kriesi, 179-201. Cambridge: Cambridge University Press.

Kriesi, Hanspeter, Edgar Grande, Romain Lachat, Martin Dolezal, Simon Bornschier, and Timotheos Frey. 2006. Globalization and the transformation of the national political space: six European countries 
compared. European Journal of Political Research 45(6):921-956. https://doi.org/10.1111/j.14756765.2006.00644.x.

Ksiazkiewicz, Aleksander, and Robert F. Krueger. 2017. The role of genes and environments in linking the need to evaluate with political ideology and political extremity. Social Justice Research 30(4):381-407. https://doi.org/10.1007/s11211-017-0292-3.

Ksiazkiewicz, Aleksander, and Seyoung Jung. 2020. The biology of political decision making. https://doi. org/10.1093/acrefore/9780190228637.013.960. Accessed 8 Feb 2021.

Lachat, Romain. 2014. Issue ownership and the vote: the effects of associative and competence ownership on issue voting. Swiss Political Science Review 20(4):727-740. https://doi.org/10.1111/spsr.12121.

Laitin, David D., and Aaron Wildavsky. 1988. Political culture and political preferences. The American Political Science Review 82(2):589-597. https://doi.org/10.2307/1957403.

Landau-Wells, Marika, and Rebecca Saxe. 2020. Political preferences and threat perception: opportunities for neuroimaging and developmental research. Current Opinion in Behavioral Sciences 34:58-63. https://doi.org/10.1016/j.cobeha.2019.12.002.

Lavine, Howard G., Christopher D. Johnston, and Marco R. Steenbergen. 2012. The ambivalent partisan: How critical loyalty promotes democracy. Oxford, New York: Oxford University Press.

Lee, Jae Kook, Jinhyang Choi, Cheonsoo Kim, and Yonghwan Kim. 2014. Social media, network heterogeneity, and opinion polarization. Journal of Communication 64(4):702-722.

Lefkofridi, Zoe, Markus Wagner, and Johanna E. Willmann. 2014. Left-authoritarians and policy representation in Western Europe: electoral choice across ideological dimensions. West European Politics 37(1):65-90. https://doi.org/10.1080/01402382.2013.818354.

Lenz, Gabriel S. 2012. Follow the leader? How voters respond to politicians' policies and performance. Chicago; London: University of Chicago Press.

Lewis-Beck, Michael S. 1985. Pocketbook voting in U.S. national election studies: fact or artifact? American Journal of Political Science 29(2):348-356. https://doi.org/10.2307/2111171.

Lewis-Beck, Michael S. 2006. Does economics still matter? Econometrics and the vote. Journal of Politics 68(1):208-212. https://doi.org/10.1111/j.1468-2508.2006.00381.x.

Lewis-Beck, Michael S., and Richard Nadeau. 2011. Economic voting theory: testing new dimensions. Electoral Studies 30(2):288-294. https://doi.org/10.1016/j.electstud.2010.09.001.

Lewis-Beck, Michael S., and Mary Stegmaier. 2019. Economic voting. In The Oxford handbook of public choice, Vol. 1, ed. Roger D. Congleton, Bernard Grofman, and Stefan Voigt, 246-265. New York: Oxford University Press.

Lipset, Seymour Martin, and Stein Rokkan. 1967. Cleavage structures, party systems and voter alignments: an introduction. In Party systems and voter alignments: cross-national perspectives. New York: Free Press.

Littvay, Levente. 2019. Twin studies and politics. In The Oxford handbook of behavioral political science, ed. Alex Mintz, Lesley Terris. Oxford: Oxford University Press. https://oxfordhandbooks.com/view/ 10.1093/oxfordhb/9780190634131.001.0001/oxfordhb-9780190634131-e-12. Accessed 8 Feb 2021.

Littvay, Levente. 2020. Genetics and heritability research on political decision making. In Oxford research encyclopedia of politics. Oxford: Oxford University Press.

Malka, Ariel, Yphtach Lelkes, Bert N. Bakker, and Eliyahu Spivack. 2020. Who is open to authoritarian governance within western democracies? Perspectives on Politics https://doi.org/10.1017/ S1537592720002091.

Margalit, Yotam. 2019. Political responses to economic shocks. Annual Review of Political Science 22(1):277-295. https://doi.org/10.1146/annurev-polisci-050517-110713.

Marino, Bruno, Nicola Martocchia Diodati, and Luca Verzichelli. 2018. From leaders to personalities? Evidence from an expert survey on personalisation of politics in Western Europe. https://www.circap.org/ uploads/1/8/1/6/18163511/circap_op_04_2018_rev.pdf. Accessed 2 Feb 2021. CIRCaP Occasional Papers series.

Markowski, Radoslaw. 2019. Creating authoritarian clientelism: Poland after 2015. Hague Journal on the Rule of Law 11(1):111-132. https://doi.org/10.1007/s40803-018-0082-5.

Merkel, Wolfgang, and Michael Zürn. 2019. Kosmopolitismus, Kommunitarismus und die Demokratie. In Internationale Gerechtigkeit und institutionelle Verantwortung, ed. Julian Nida-Rümelin, Julian Daniels, and Detlef von Wloka, 67-101. Berlin: De Gruyter. https://doi.org/10.1515/9783110615876007.

Messing, Solomon, and Sean J. Westwood. 2014. Selective exposure in the age of social media: endorsements trump partisan source affiliation when selecting news online. Communication Research 41(8):1042-1063. https://doi.org/10.1177/0093650212466406. 
Müller, Walter, and Markus Klein. 2012. Die Klassenbasis in der Parteipräferenz des deutschen Wählers. Erosion oder Wandel? Wählen in Deutschland (Special Issue Politische Vierteljahresschrift 45/2011:92-117. https://doi.org/10.5771/9783845262178_92.

Mullinix, Kevin J. 2018. Civic duty and political preference formation. Political Research Quarterly 71(1):199-214. https://doi.org/10.1177/1065912917729037.

Neufeld, John, William Hausman, and Ronald Rapoport. 1994. A paradox of voting: cyclical majorities and the case of muscle shoals. Political Research Quarterly https://doi.org/10.2307/449018.

Newell, Allen. 1990. Unified theories of cognition. Cambridge: Harvard University Press.

Norris, Pippa, and Ronald Inglehart. 2019. Cultural backlash: Trump, Brexit, and authoritarian populism. Cambridge: Cambridge University Press.

Oesch, Daniel. 2006. Coming to grips with a changing class structure: an analysis of employment stratification in britain, Germany, Sweden and Switzerland. International Sociology 21(2):263-288. https:// doi.org/10.1177/0268580906061379.

Oesch, Daniel. 2008. Explaining workers' support for right-wing populist parties in Western Europe: evidence from Austria, Belgium, France, Norway, and Switzerland. International Political Science Review 29(3):349-373. https://doi.org/10.1177/0192512107088390.

Oesch, Daniel. 2012. The class basis of the cleavage between the New Left and the radical right: an analysis for Austria, Denmark, Norway and Switzerland. In Class politics and the radical right, ed. Jens Rydgren. London, New York: Routledge.

Pedersen, Helene Helboe, and Gideon Rahat. 2019. Introduction: political personalization and personalized politics within and beyond the behavioural arena. Party Politics https://doi.org/10.1177/ 1354068819855712.

Petrocik, John R. 1996. Issue ownership in presidential elections, with a 1980 case study. American Journal of Political Science 40(3):825-850. https://doi.org/10.2307/2111797.

Pillai, Rajnandini, and Ethlyn A. Williams. 1998. Does leadership matter in the political arena? Voter perceptions of candidates' transformational and charismatic leadership and the 1996 U.S. president. The Leadership Quarterly 9(3):397-416.

Pillai, Rajnandini, A. Williams Ethlyn, Kevin B. Lowe, and Dong I. Jung. 2003. Personality, transformational leadership, trust, and the 2000 U.S. presidential vote. The Leadership Quarterly 14(2):161-192.

Plescia, Carolina, and Julian Aichholzer. 2017. On the nature of voters' coalition preferences. Journal of Elections, Public Opinion and Parties 27(3):254-273. https://doi.org/10.1080/17457289.2016. 1270286.

Poguntke, Thomas, and Paul Webb (eds.). 2005. The presidentialization of politics a comparative study of modern democracies. Oxford; New York: Oxford University Press.

Pruysers, Scott, William P. Cross, and Richard S. Katz. 2018. Personalism, personalization and party politics. In The personalization of democratic politics and the challenge for political parties, ed. William P. Cross, Richard S. Katz, and Scott Pruysers, 1-18. London; New York: Colchester: Littlefield International; ECPR Press.

Rahat, Gideon, and Ofer Kenig. 2018. From party politics to personalized politics? Party change and political personalization in democracies. Oxford: Oxford University Press.

Rawls, John. 1971. A theory of justice. Cambridge: Harvard University Press.

Rehm, Philipp. 2009. Risks and redistribution: an individual-level analysis. Comparative Political Studies 42(7):855-881. https://doi.org/10.1177/0010414008330595.

Rehm, Philipp, Jacob S. Hacker, and Mark Schlesinger. 2012. Insecure alliances: risk, inequality, and support for the welfare state. The American Political Science Review 106(2):386-406.

Riker, William H. 1982. Liberalism against populism: a confrontation between the theory of democracy and the theory of social choice. San Francisco: W.H. Freeman.

Riker, William H. 1986. The art of political manipulation. New Haven: Yale University Press.

Ringe, Nils. 2005. Policy preference formation in legislative politics: Structures, actors, and focal points. American Journal of Political Science 49(4):731-745. https://doi.org/10.1111/j.1540-5907.2005. 00151.x.

Rommel, Tobias, and Stefanie Walter. 2018. The electoral consequences of offshoring: how the globalization of production shapes party preferences. Comparative Political Studies 51(5):621-658. https:// doi.org/10.1177/0010414017710264.

Rovny, Jan. 2013. Where do radical right parties stand? Position blurring in multidimensional competition. European Political Science Review 5(1):1-26. https://doi.org/10.1017/S1755773911000282.

Rueda, David. 2007. Social democracy inside out: partisanship and labor market policy in advanced industrialized democracies. Oxford: Oxford University Press. 
Rueda, David, and Daniel Stegmueller. 2019. Who wants what? Redistribution preferences in comparative perspective. Cambridge: Cambridge University Press.

Schedler, Andreas, and Rodolfo Sarsfield. 2007. Democrats with adjectives: linking direct and indirect measures of democratic support. European Journal of Political Research 46:637-659. https://doi.org/ 10.1111/j.1475-6765.2007.00708.x.

Schwander, Hanna. 2019. Labor market dualization and insider-outsider divides: why this new conflict matters. Political Studies Review 17(1):14-29. https://doi.org/10.1177/1478929918790872.

Shamir, Boas. 1994. Ideological position, leaders' charisma, and voting preferences: personal vs. partisan elections. Political Behavior 16(2):265-287.

Shamir, Boas. 2009. From passive recipients to active co-producers: followers' role in the leadership process. In Follower-centered perspectives on leadership: a tribute to the memory of James R. Meindl, ed. Boas Shamir, Rajnandini Pillai, Michelle C. Bligh, and Mary Uhl-Bien, ix-xxxix. Greenwich: Information Age Publishing.

Stadelmann, David, Marco Portmann, and Reiner Eichenberger. 2019. Preference representation and the influence of political parties in majoritarian vs. proportional systems: an empirical test. British Journal of Political Science 49(1):181-204. https://doi.org/10.1017/S0007123416000399.

Stam, Allan C., Alexander Von Hagen-Jamar, and Alton B.H. Worthington. 2012. Fear and attitudes towards torture and preventive war. Twin Research and Human Genetics 15(1):60-70. https://doi.org/ 10.1375/twin.15.1.60.

Steffens, Niklas K., S. Alexander Haslam, and Stephen D. Reicher. 2014. Up close and personal: evidence that shared social identity is a basis for the 'special' relationship that binds followers to leaders. The Leadership Quarterly 25(2):296-313.

Stubager, Rune, and Rune Slothuus. 2013. What are the sources of political parties' issue ownership? Testing four explanations at the individual level. Political Behavior 35(3):567-588. https://doi.org/ 10.1007/s11109-012-9204-2.

Thewissen, Stefan, and David Rueda. 2019. Automation and the welfare state: technological change as a determinant of redistribution preferences. Comparative Political Studies 52(2):171-208. https:// doi.org/10.1177/0010414017740600.

Tsebelis, George. 2002. Veto players: how political institutions work. : Princeton University Press.

Tucker, Joshua A., Andrew Guess, Pablo Barbera, Cristian Vaccari, Alexandra Siegel, Sergey Sanovich, et al. 2018. Social media, political polarization, and political disinformation: a review of the scientific literature. https://hdl.handle.net/2134/37088. Accessed 20 Jan 2021. Loughborough University. Report.

Van Der Brug, Wouter, and Joost Van Spanje. 2009. Immigration, Europe and the 'new' cultural dimension. European Journal of Political Research 48(3):309-334. https://doi.org/10.1111/j.1475-6765.2009. 00841.x.

Vassallo, Francesca. 2020. Social capital. In Oxford research encyclopedia of politics. Oxford: Oxford University Press. https://doi.org/10.1093/acrefore/9780190228637.013.70.

Weinschenk, Aaron C., Christopher T. Dawes, Sven Oskarsson, Robert Klemmensen, and Asbjørn Sonne Nørgaard. 2021. The relationship between political attitudes and political participation: evidence from monozygotic twins in the United States, Sweden, Germany, and Denmark. Electoral Studies 69:102269. https://doi.org/10.1016/j.electstud.2020.102269.

Williams, Ethlyn A., Rajnandini Pillai, Bryan J. Deptula, Kevin B. Lowe, and Kate McCombs. 2018. Did charisma 'Trump' narcissism in 2016? Leader narcissism, attributed charisma, value congruence and voter choice. Personality and Individual Differences 130:11-17.

Wren, Anne, and Philipp Rehm. 2013. Service expansion, international exposure, and political preferences. In The political economy of the service transition, ed. Anne Wren, 248-281. Oxford: Oxford University Press.

Zaller, John R. 1992. The nature and origins of mass opinion. Cambridge: Cambridge University Press.

Zaller, John, and Stanley Feldman. 1992. A simple theory of the survey response: answering questions versus revealing preferences. American Journal of Political Science 36(3):579-616. https://doi.org/ $10.2307 / 2111583$. 